\title{
24
}

\section{Childcare Indicators for the Next Generation of Research}

\author{
Sebastian Sirén, Laure Doctrinal, Wim Van Lancker, \\ and Rense Nieuwenhuis
}

\section{Introduction}

The contributions to this handbook are all testimonies of the significant progress that has been made during the last couple of decades in terms of mapping policies and analyzing the associated political processes and impacts across countries, time, and multiple levels of policy-making. The existing literature arguably also reflects how the availability of data on relevant aspects of family policy shapes the research conducted and the kind of questions researchers are able to answer. Further advancements of this research agenda, as envisioned in several of the preceding contributions, as well as in the final and concluding chapter of this book, are accordingly also constrained by the restricted availability of relevant indicators on important aspects of

\section{S. Sirén · L. Doctrinal}

Swedish Institute for Social Research, Stockholm University, Stockholm, Sweden e-mail: sebastian.siren@sofi.su.se

L. Doctrinal

e-mail: laure.doctrinal@sofi.su.se

W. Van Lancker $(\bowtie)$

Centre for Sociological Research, University of Leuven, Leuven, Belgium e-mail:wim.vanlancker@kuleuven.be

R. Nieuwenhuis

Swedish Institute for Social Research (SOFI), Stockholm University, Stockholm, Sweden

e-mail: rense.nieuwenhuis@sofi.su.se 
institutional variation across countries. Pushing the availability of policyrelated indicators further should accordingly be a primary concern for those interested in the development of this research field.

In this chapter, we elaborate on the need to develop theoretically grounded family policy indicators. Since an encompassing overview of all family-related policies is beyond the scope of this chapter, we will focus specifically on early childhood education and care (ECEC, in the remainder referred to as childcare), an area for which the development of relevant policy indicators is clearly challenging, but where overcoming these challenges is a precondition to achieve further scientific progress. Although we limit the discussion in this chapter to this specific policy field, the insights highlighted below very much reflect issues that are relevant to scholars within the area of family policy research more broadly.

The first section of this chapter critically introduces the conceptual frameworks underpinning the most prevalent currents in comparative research. The next section then presents the most prominent empirical approaches utilized in existing studies, and how these depend on the availability of relevant data as well as the analytical outlooks of the respective scholars. The third section then maps the availability of comparative data on the most widely used indicators and discusses the main sources from which this data originates. The final section concludes by pointing toward some challenges for the current research agenda, along with some tentative solutions. In particular, we argue for the need to engage in the development of indicators on social rights, reflecting the institutional variation across countries, across time, as well as across various levels of policy-making, with regard to childcare in particular and family policy in general.

\section{Conceptualizing the Role of Policy in Comparative Research on Childcare}

The historical changes in the organization of our societies and the (at least partial) recasting of traditional gender roles within the familial sphere, have created new needs and real challenges for existing family policies (Daly, 2011; Lewis, 2001; Montanari, 2000). While undoubtedly driven by the emancipatory struggles of the women's movement, the weakening of the male breadwinner model and the increased marital instability has in recent decades been described as generating "new social risks" to which increasing women's employment is proposed as a functional solution (Armingeon \& Bonoli, 2006). Along the same lines, the recognition of gender equality and the challenges associated with changing family arrangements have been incorporated 
as distinctive features of the social investment discourse, which surfaced as a central paradigm in debates about the future of welfare states (Saraceno, 2017). Partly as a result of this turn, much interest has recently been oriented toward the variation of public provisions that facilitate the reconciliation of work and family life (Abendroth \& Den Dulk, 2011; Hegewisch \& Gornick, 2011; OECD, 2007; Plantenga \& Remery, 2005), of which childcare services constitute a cornerstone.

Childcare services are accordingly considered instrumental in fostering mothers' employment (Gornick, Meyers, \& Ross, 1997; Keck \& Saraceno, 2013; Olivetti \& Petrongolo, 2017) and greater gender equality in earnings (Evertsson et al., 2009; Grönlund \& Magnusson, 2016; Nieuwenhuis, Need, \& Van der Kolk, 2019). Childcare policy is moreover often promoted as a tool to reduce the risk of vulnerable families falling into poverty, by allowing mothers, and especially single mothers, to remain in employment (Maldonado \& Nieuwenhuis, 2015; Misra, Moller, Strader, \& Wemlinger, 2012). Finally, childcare services of high quality are also conducive for cognitive and noncognitive development of children as well, improving school readiness of, in particular, disadvantaged children. This allows for longer-term improvements in social mobility and poverty (Cunha \& Heckman, 2007; Leseman \& Slot, 2014; see Chapter 8 by Vandenbroeck in this volume). As a result, childcare provision has risen high on the agenda of international organizations such as the OECD (2017) and the European Commission (2013), unmistakably demonstrated in the proposal for a directive on worklife balance for parents and carers as part of the European pillar for social rights (European Commission, 2017; see also Chapter 3 by Jenson in this volume).

This development clearly reflects the increasing traction of the "adult worker" as an emerging norm in international discourses (Daly, 2011; Lewis \& Giullari, 2005). Analytically, these trends are often conceptualized in terms of "defamilization," defined as the degree to which one's dependency on the family is lessened by provisions from the state or by recourse to the market (Leitner \& Lessenich, 2007; Lohmann \& Zagel, 2016; see also Chapter 6 by Zagel \& Lohmann in this volume). These and associated concepts are then often used to construct clusters of countries adhering principally to each of these policy orientations, respectively (Ferrarini, 2006; Korpi, 2000; Leitner, 2003; Saraceno \& Keck, 2010).

Critics of how care is treated within the social investment framework have pertinently highlighted the tendency to promote defamilization of care as a means toward the commodification of women's work, in order to counter poverty risks and falling fertility rates associated with changing 
family arrangements (e.g., Esping-Andersen, Gallie, Hemerijck, \& Myles, 2002). Thereby such a discourse runs the risk of contributing to a devaluation of unpaid care work traditionally carried out by women in the position of mothers, daughters, or spouses (Daly, 2011; Jenson, 2009; Saraceno, 2017). Likewise, an instrumental focus on child development and maternal employment leaves little room for women's agency and choice, for example, to organize childcare according to their own desires (Yerkes \& Javornik, 2018). Similarly, while the role of childcare policies for greater equality of opportunity in coming generations is becoming widely recognized (Burger, 2013; Esping-Andersen, 2015), current policy-oriented research generally takes the parents or the family as the main subject of study. Children are in this context often perceived as "becomings," rather than "beings" (Lister, 2003), and are thus devoid of inherent rights and agency (Daly, 2019).

The conceptual frameworks used in much of the existing literature often conflate causes, institutions, and outcomes, thereby encumbering analyses of causal relationships between these (Korpi, 2000; see also Chapter 6 by Zagel \& Lohmann in this volume). The current ambition in the literature to move toward explanatory analyses of how institutions evolve and subsequently shape outcomes thus requires critical re-examination of existing concepts. While separate indicators on outcomes tend to be relatively accessible, an increased awareness vis-à-vis the role of institutional variation highlights the need to develop conceptually informed indicators also in this regard. The increasingly common emphasis on the multidimensionality of family policies also points toward a need for these indicators to reflect qualitative differences between different modes of provision (Keck \& Saraceno, 2013; Korpi, Ferrarini, \& Englund, 2013; Pettit \& Hook, 2009; Yerkes \& Javornik, 2018).

\section{Empirical Approaches in Previous Research}

In line with the divergent historical patterns of family arrangements and policy developments, childcare policies show considerable cross-country variation. Roughly since the mid-1990s, a number of studies have sought to classify systems of childcare services (Anttonen \& Sipilä, 1996; Gornick et al., 1997; Kamerman, 2000; OECD, 2001; Randall, 2000; Rauch, 2007; Rostgaard, 2002; Saraceno \& Keck, 2010). As a result of these and other research efforts, there seems to be widespread consensus that ideal childcare policies ensure that the services are available, affordable, and of good quality (Gambaro, Stewart, \& Waldfogel, 2015; see also Chapter 8 by Vandenbroeck in this volume). These three dimensions are interrelated to some extent. For 
a service to be affordable and/or providing high-quality care, it needs to be available in the first place (Yerkes \& Javornik, 2018). Affordable childcare will fail to increase the number of children enrolled if their parents do not have access to childcare places. However, comprehensive collection of comparable indicators on all three dimensions that could allow for systematic quantitative analyses of the institutional configuration of childcare services and their consequences is still scarcely developed.

In the literature on social policy in general, and family policy in particular, three types of policy indicators can be discerned: (1) indicators based on expenditure data; (2) indicators capturing receipt and usage of policies based on survey or administrative data; and (3) indicators capturing the design of policies based on institutional or legislative data (Marchal \& Van Lancker, 2019; Otto, 2018). Many comparative studies of childcare provisions have used public expenditures and enrolment rates as the main policy indicators (Bonoli \& Reber, 2010; Huber \& Stephens, 2000; Jensen, 2009; Pavolini \& Van Lancker, 2018; Rauch, 2007). As the levels of expenditure on these services is largely a function of their take-up, it should come as no surprise that these indicators are highly correlated (Jensen, 2009, p. 12). Both measures accordingly share a number of features with implications for their usefulness in comparative research.

Like in other fields of social policy studies, expenditure data have figured prominently as an indicator of public effort and the degree of socialization of family-related activities. As a result of increased efforts by international organizations, government spending has been systematically collected for a significant number of countries, at least across the affluent welfare states of the OECD. Also, disaggregated expenditure data for different subsets of policies, separating spending on parental leave, child benefits, and childcare services, have become increasingly available (Bonoli \& Reber, 2010; Castles, 2003). Still, expenditure data suffers from drawbacks not always recognized in the literature. Especially, changes in expenditure levels not necessarily reflect qualitative changes in policies, since these can also be driven by demographic changes. Such measures are also strongly influenced by short-term fluctuations in the denominator, in this case often GDP, especially during times of economic turmoil. To account for this, spending indicators should be adjusted for need as well as for GDP fluctuations (Otto, 2018). This however affects the interpretability of the indicator.

Other issues cannot be readily solved. Varying definitions and principles for data collection, for example, might weaken the comparability of spending indicators. These inconsistencies can result from different funding streams not adequately captured in the data, especially regarding expenditure 
at levels below the national government, as well as fiscal expenditures. This is particularly relevant for childcare, as these services are provided by regional and/or local governments in many countries (Javornik, 2014), while other countries subsidize families using childcare services through the tax system. Finally, changes in spending, even if they are adjusted for need and economic cycles, can mean different things in different policy contexts. An increase in spending on childcare could refer to an increase in the generosity of vouchers in one country or to an increase in the number of available places in the other. The outcomes of these two parametric changes are likely to be substantially different.

As an alternative, many studies have relied on survey or administrative data to calculate measures of the uptake of childcare policies, in the form of enrolment rates (OECD, 2007; Pavolini \& Van Lancker, 2018; Plantenga \& Remery, 2009; Thévenon, 2011). In particular, the efforts by Eurostat, the European statistical office, to collect harmonized statistics on the take-up of childcare services in the European Union Statistics on Income and Living Conditions (EU-SILC) surveys, made these indicators increasingly available to researchers. However, enrolment rates and expenditures are inherently problematic when used as an indicator of government effort, or more generally as an indicator of public policy (see Clasen \& Siegel, 2007). The main reason is that such measures are functions of both state provision and public demand, and that the uptake of a policy as well as the resulting expenditure levels should essentially be seen as outcomes rather than policy variables (Kangas \& Palme, 2007). Supply of childcare places is indeed influenced by public policies, while the demand for childcare is shaped mostly by the number of working mothers, which in turn is a product of prevailing norms, labor market conditions, and other related policies (Javornik, 2014). As a result, childcare enrolment and expenditure may change in a country even if there is no change in public policy in that area, for instance in times of high unemployment or changing ideals regarding parental care (Evertsson \& Grunow, 2016).

Accordingly, aggregates such as expenditures or enrolment rates reveal little about the "nuts and bolts" of national childcare systems, including features related to relevant aspects such as availability, affordability, and quality. Nor do such aggregate indicators allow for examining how features of policies affect specific subgroups of the population differently. This is a significant shortcoming as the causes of social stratification related to work-family reconciliation measures is a major concern in current scholarship (Chapter 11 by Hook \& Li; Bonoli, Cantillon, \& Van Lancker, 2017; Korpi et al., 2013; Pavolini \& Van Lancker, 2018; Pettit \& Hook, 2009; Van Lancker \& Ghysels, 2016; Yerkes \& Javornik, 2018). Additionally, addressing complex 
interactions between different sets of policies that often jointly produce the outcomes that scholars of family policy impacts are concerned with, requires detailed information on policy design (Javornik, 2014). Within the domain of family policy, the interaction between leave policies and childcare provision is one such theme (Blum, Koslowski, Macht, \& Moss, 2018). Another is the extent to which availability, affordability, and quality jointly shapes the uptake of childcare among different categories of families (Yerkes \& Javornik, 2018). Data that would allow analyzing such interactions are however scarce, and this situation becomes particularly dissatisfying as the research agenda aims to move from descriptive toward explanatory ambitions.

As an alternative to expenditures and take-up, institutional indicators reflecting the actual entitlements of families have been solicited (Hegewisch \& Gornick, 2011; Javornik, 2014; Korpi et al., 2013; Nieuwenhuis, Need, \& Van Der Kolk, 2012). Such an institutional approach has previously been proposed as an operationalization of the concept of social rights, applicable across different welfare states and policy fields (Korpi, 2000; Marshall, 1950; Orloff, 1993). This has been the guiding principle of some of the most cited empirical works within comparative welfare state research more broadly (Allan \& Scruggs, 2004; Esping-Andersen, 1990; Korpi \& Palme, 1998), but the development of equivalent indicators regarding childcare services is still in its infancy.

Such indicators are generated by systematizing legislative information into indicators of entitlements or social rights, and can be presented in textual form. However, in order to reduce the level of complexity and thereby facilitate comparative statistical analyses, these indicators are often expressed in quantitative terms. In practice, such quantitative indicators are constructed using model family methods, by which benefit levels and other institutional features are deduced based on assumptions regarding household compositions and employment status (Bradshaw, Ditch, Holmes, \& Whiteford, 1993). By holding such factors constant across observations this methodology aims to provide a measure of the temporal and cross-sectional variation in the institutional design of family policies. Researchers have come a long way in constructing useful comparative datasets along these lines regarding cash benefits, including child benefits, paid parental leave, and family-related tax credits, (Ferrarini, 2006; Gauthier, 1996; Saraceno \& Keck, 2008; Van Mechelen, Marchal, Goedemé, Marx, \& Cantillon, 2011). Institutional indicators have moreover been applied to study differences in policy design between distinct welfare states (Ferrarini, 2006; Ferrarini, Nelson, \& Höög, 2012; Javornik, 2014; Korpi, 2000; Marchal \& Van Lancker, 2019), as well as the impact of such differences on poverty and 
inequality (Bäckman \& Ferrarini, 2010; Keck \& Saraceno, 2013; Korpi et al., 2013; Misra et al., 2012; Nieuwenhuis et al., 2019; Pettit \& Hook, 2009; Van Lancker \& Van Mechelen, 2015). Institutional indicators have been employed to study the extent to which policies support female, and especially maternal, employment (Hegewisch \& Gornick, 2011; Nieuwenhuis et al., 2012; Pettit \& Hook, 2005), and to which family policies are conducive toward independence from family relationships, in terms of defamilization (Javornik, 2014; Leitner, 2003; Leitner \& Lessenich, 2007; Lohmann \& Zagel, 2016; see also Chapter 6 by Zagel \& Lohmann in this volume). Such indicators also featured in discussions about how family policies influence the range of opportunities actually available to families in contemporary political economies, in terms of families' "capability sets" (Hobson, 2013; Yerkes, Jana, \& Kurowska, 2019; Chapter 7 by Javornik \& Yerkes).

Continuous measures based on institutional information, often in combination with indicators on outcomes such as labor market structures and incomes, have moreover been used by several scholars to classify countries into different ideal-typical family policy or care regimes (Anttonen \& Sipilä, 1996; Bettio \& Plantenga, 2004; Leitner, 2003; Meyers \& Gornick, 2003; Saraceno \& Keck, 2010). While ideal-typical welfare state regimes can be important theoretical constructs and useful to demonstrate systematic differences between countries, or to present country variation in a concise manner, their analytical usefulness is however limited. The limitations of the regime approach are related to the difficulties in accounting for differences within clusters, changes over time, specific features of policy designs, and their interactions with other policies (for an approach that remedies some of these shortcomings see Javornik, 2014).

\section{Databases on Childcare Services: The State of Affairs}

As discernible from the preceding sections, comparative studies of childcare systems based on quantitative indicators have been facilitated by several important data collection efforts. An early example is that of the European Commission Childcare Network (Gauthier, 2000), which through a series of reports reviewed the childcare services and policies throughout the European Union (Cohen, 1989; Moss, 1990, 1996). Although primarily descriptive in their contents, these publications nevertheless provided a broad documentation of childcare provision in Europe, opening the field for further research based on these data and the development of a number of new datasets in 
the field. For example, Kamerman (2000) constructed a range of indicators, some based on this data, to develop a typology of childcare services in the OECD, differentiating systems by age of children, administrative auspices, and types of providers. In another study, Gornick et al. (1997) mapped the provisions of a number of family policy areas, including publicly regulated and subsidized childcare, linking such provisions to the employment of mothers. The data collected for this latter study was subsequently deposited with the Luxembourg Income Study (LIS) data center and made available to the public.

The important progress made in this field during the 1990s caused observers to proclaim that "the provision at national level of publicly funded services providing care for children with employed parents (at least up to ten years of age) [...] is by now fairly well mapped" (Deven et al., 1999, p. 5). Nevertheless, a subsequent report from Eurostat underlined the weaknesses and limits of the available statistics, pointing out the difficulty "to obtain comparable statistics covering childcare services" (Eurostat, 2004, p. 1). The issue lay largely in the harmonization of statistics available at the national level. In particular, the way data were collected varied widely between countries, for example, regarding the method of data collection (survey or administrative data) or the categories used when coding the data (age groups, attendance, source of funding, type of childcare considered). The report concluded that the figures presented with regard to coverage and enrolment of children "should be treated with a great deal of caution, especially as regards their comparability between countries" (Eurostat, 2004, p. 29).

With the adoption of the Barcelona targets by the European Council in 2002, introducing explicit goals for the expansion of childcare services on offer, the need to monitor progress was brought into the spotlight. The subsequent need to map and evaluate childcare policies underscored the deficit in existing comparable data and prompted the inclusion of childcare indicators in the EU-SILC survey as a solution (Plantenga \& Remery, 2009). In 2005, with most Member States covered, the EU-SILC became the reference source for statistics about childcare, used among others by the European Commission to measure the attainment of the Barcelona objectives.

The definition of formal childcare in EU-SILC covers preschool or equivalent, compulsory education, as well as professional childminders and centerbased childcare services, including out-of-school care, irrespective of the provider. A distinction is also made between full and part-time care, with the threshold set at 30 hours per week. Figures are moreover available on the use of informal forms of childcare, including friends and family members other 
than the parents. The Eurostat statistics based on EU-SILC also report aggregated data on the average duration of childcare per week in each country. Data are updated on a yearly basis. In 2016, variables referring to the affordability of childcare services, unmet needs for such services, and reasons for not making use of such services were added through an ad hoc module.

The OECD made use of these indicators, complementing them with information regarding non-European OECD countries, to set up a comparative database on family policies (Adema, Huerta, Panzera, Thévenon, \& Pearson, 2009; OECD, 2007). These increased efforts by international entities to collect and publish comparative indicators have meant important progress toward increasing the cross-country comparability of data on childcare services, and have rendered a number of studies analyzing the impact of childcare policies, mainly with regard to inequality, labor market, and fertility outcomes (e.g., Kröger, 2011; Pavolini \& Van Lancker, 2018; Thévenon, 2011; Thévenon \& Solaz, 2014; Van Lancker \& Ghysels, 2016).

Although the EU-SILC overcomes previous difficulties in terms of data harmonization, certain issues remain, several of which are mentioned in the report of the European Commission (2013) about the attainment of the Barcelona objectives. Data on the percentage of children under 3 cared for in formal structures in 2010-2011 are for instance "compiled from small samples and are statistically unreliable" for several countries ${ }^{1}$ (European Commission, 2013, p. 7). Moreover, conceptual and methodological problems, for instance, regarding the lack of distinction between private and public provision of childcare, the small sample sizes for more than half of the countries in the survey, and errors in the coding process have been noted by others as well (Keck \& Saraceno, 2011).

This is a real issue. In the questions on childcare enrolment in EU-SILC, a distinction is made between compulsory school (ISCED 1), preschool (ISCED 0), and formal childcare services (including crèches, childcare centers, and paid childminders which is a common way of organizing formal childcare in many countries). However, these different categories do not always match the types of services and preschools or the common age of enrolment in these services in particular countries. In England, for example, according to official numbers $72 \%$ of 2 -year olds were enrolled in early education places in 2018, including private providers, state-funded primary schools and nurseries, and childminders (Department for Education, 2019). For 3to 4-year olds, this was $95 \%$. Our own calculations based on the EU-SILC data for 2018 show that $66 \%$ of 2 -year olds were enrolled in early education

\footnotetext{
${ }^{1}$ The countries for which issues of reliability are raised are: Austria, Bulgaria, Cyprus, Czech Republic, Greece, Hungary, Lithuania, Malta, Poland, Romania, and Slovakia.
} 
places, increasing to $83 \%$ for 3- to 4-year olds. Formal registration of enrolment of children does not need to be the same as coverage rates referring to the number of children being in formal childcare service during the past week, as it is asked in the EU-SILC questionnaire. But still, the difference is striking, and there is no apparent explanation for it.

A possible explanation is that questions are misunderstood by the respondents. To give one example, in the EU-SILC questionnaire, parents are asked to provide the number of hours each child spends in compulsory school, preschool, and/or formal childcare services during a regular week. The distribution of the responses sometimes indicates that parents interpreted this as number of hours per day, with mean scores of 7 (e.g., in EU-SILC 2012 for compulsory school in the UK) or 5.8 (childcare at center-based services in the UK in EU-SILC 2018). Finally, tracking evolutions in childcare coverage over time seems to be a problem for some countries as well. For instance, Eurostat (2019) data for Italy reports childcare coverage for under threes of $27 \%$ in 2008 , dropping to $20 \%$ in 2012 , increasing to $34.4 \%$ in 2016 , only to drop again to $25.7 \%$ in 2018 . Yet, there is no concomitant change to be observed in terms of expenditure on childcare in Italy (own calculations based on the OECD Social Expenditures database). The real issue here is that these problems are hardly or not even documented in the yearly quality reports released by Eurostat (Eurostat, 2020). Nevertheless, EU-SILC remains a prominent source of data on childcare services, in particular with regard to enrolment rates.

Apart from Eurostat and the OECD, a number of additional entities have compiled and published comparative indicators on the organization of childcare services. Table 24.1 gives a non-exhaustive overview of existing databases, as regards their geographical coverage as well as information regarding whether or not they are still updated and the last year for which data are available. As pertinently highlighted in the framing of this handbook, family policies in general, and perhaps particularly childcare services, are formulated and implemented at different levels. The role of supranational organizations in issuing recommendations and collecting data has been touched on above. As have the decisive role of regional and local authorities in providing services and regulating nonpublic providers. Despite this, previous research has almost unanimously focused on variation on the national level, partly for reasons of data availability but also given the theoretical underpinnings of studies and the need to reduce complexity in order to make comparisons possible. All databases reviewed below accordingly refer to the national level. 
Table 24.1 Geographical coverage and updating of databases

\begin{tabular}{|c|c|c|}
\hline Database & Geographical coverage & $\begin{array}{l}\text { Still updated (last year } \\
\text { for which data are } \\
\text { available) }\end{array}$ \\
\hline Family policy database & $\begin{array}{l}\text { Australia, Belgium, } \\
\text { Canada, Denmark, } \\
\text { Finland, France, } \\
\text { Germany, Italy, } \\
\text { Luxembourg, } \\
\text { Netherlands, Norway, } \\
\text { Sweden, United } \\
\text { Kingdom, United States }\end{array}$ & no (2003) \\
\hline Multilinks & $\begin{array}{l}\text { European Union ( } 27 \\
\text { countries), Georgia, } \\
\text { Norway, Russia }\end{array}$ & no (2009) \\
\hline $\begin{array}{l}\text { Work-family policy } \\
\text { indicators }\end{array}$ & $\begin{array}{l}\text { European Union (15 } \\
\text { countries), Australia, } \\
\text { Czech Rep., Hungary, } \\
\text { Israel, Poland, Russian } \\
\text { Federation, Slovak Rep., } \\
\text { United States }\end{array}$ & no (2012) \\
\hline EU-SILC & $\begin{array}{l}\text { European Union ( } 28 \\
\text { countries), Iceland, } \\
\text { Norway, Switzerland, } \\
\text { Noth Macedonia, Serbia, } \\
\text { Turkey }\end{array}$ & yes (2018) \\
\hline Eurydice & $\begin{array}{l}\text { European Union ( } 28 \\
\text { countries), Albania, } \\
\text { Bosnia and Herzegovina, } \\
\text { Switzerland, Iceland, } \\
\text { Liechtenstein, } \\
\text { Montenegro, North } \\
\text { Macedonia, Norway, } \\
\text { Serbia and Turkey }\end{array}$ & yes (2018-2019) \\
\hline $\begin{array}{l}\text { NOSOSCO (Nordic Social } \\
\text { Statistical Committee) }\end{array}$ & $\begin{array}{l}\text { Denmark, Faroe Islands, } \\
\text { Finland, Iceland, Norway, } \\
\text { Sweden }\end{array}$ & yes (2017) \\
\hline $\begin{array}{l}\text { Cesifo DICE (Database for } \\
\text { Institutional Comparisons } \\
\text { of Economies) }\end{array}$ & $\begin{array}{l}\text { European Union ( } 28 \\
\text { countries), Albania, } \\
\text { Bosnia and Herzegovina, } \\
\text { Former Yugoslav } \\
\text { Republic of Macedonia, } \\
\text { Iceland, Liechtenstein, } \\
\text { Montenegro, Norway, } \\
\text { Serbia, Turkey }\end{array}$ & no $(2012 / 13)$ \\
\hline
\end{tabular}


Table 24.1 (continued)

\begin{tabular}{|c|c|c|}
\hline Database & Geographical coverage & $\begin{array}{l}\text { Still updated (last year } \\
\text { for which data are } \\
\text { available) }^{a}\end{array}$ \\
\hline OECD family database & OECD countries & yes (2017) \\
\hline $\begin{array}{l}\text { TransMONEE } \\
\text { (Transformative } \\
\text { Monitoring for Enhanced } \\
\text { Equity) }\end{array}$ & $\begin{array}{l}\text { Albania, Armenia, } \\
\text { Azerbaijan, Belarus, } \\
\text { Bosnia and Herzegovina, } \\
\text { Bulgaria, Croatia, Czech } \\
\text { Rep., Estonia, Georgia, } \\
\text { Hungary, Kazakhstan, } \\
\text { Kyrgyzstan, Latvia, } \\
\text { Lithuania, Montenegro, } \\
\text { Poland, Rep. of Moldova, } \\
\text { Romania, Russian } \\
\text { Federation, Serbia, } \\
\text { Slovakia, Slovenia, } \\
\text { Tajikistan, the former } \\
\text { Yugoslav Rep. of } \\
\text { Macedonia, } \\
\text { Turkmenistan, Ukraine, } \\
\text { Uzbekistan }\end{array}$ & yes (2014-2015) \\
\hline $\begin{array}{l}\text { UNECE (United Nations } \\
\text { Economic Commission for } \\
\text { Europe) }\end{array}$ & $\begin{array}{l}\text { European Union (28 } \\
\text { countries), Albania, } \\
\text { Armenia, Azerbaijan, } \\
\text { Belarus, Bosnia and } \\
\text { Herzegovina, Canada, } \\
\text { Georgia, Iceland, Israel, } \\
\text { Kazakhstan, Kyrgyzstan, } \\
\text { Rep. of Moldova, } \\
\text { Montenegro, Norway, } \\
\text { Russian Federation, } \\
\text { Serbia, Tajikistan, the } \\
\text { former Yugoslav Rep. Of } \\
\text { Macedonia, Turkey, } \\
\text { Turkmenistan, Ukraine, } \\
\text { United States, Uzbekistan }\end{array}$ & yes (2015-2016) \\
\hline
\end{tabular}

aLast checked in May 2020. For references, see Sect. "Databases Included in the Tables"

The geographical coverage varies somewhat across the databases. While West European countries are included in all databases, except in the TransMONEE database, East European and Central Asian countries feature only in the UNECE and TransMONEE datasets. ${ }^{2}$ The NOSOSCO database collects data regarding Nordic countries only. Data are generally available

\footnotetext{
${ }^{2}$ The Cesifo DICE report also includes some East European countries on the top of those included in the EU.
} 
for fewer countries with regard to care services for the youngest children, compared to preprimary education services. Most databases are regularly updated with new waves of data, with the exception of Multilinks, the Family policy database, and the Work-family policy indicators.

The Family policy database, DICE, and the Work-family policy indicators provide data collected in several countries but referring to a single point in time. Other databases provide longitudinal data, although data availability varies across countries and indicators. In general, data about childcare in Central and Eastern European countries, as well as Latin America, African and Asian countries is scarce, especially as regards the quality and the affordability of childcare services.

Comparing the different datasets reveals some of the challenges involved when trying to find valid indicators, in particular as regards the conceptualizations of childcare formulated in relation to each database. The definition of formal childcare sometimes covers different realities depending on what kind of service is included in the definition. The OECD Family Database, for example, includes children enrolled with registered childminders, while other databases, such as the LIS Family Policy Database, excludes them. A central issue in most databases is that it is often not possible to distinguish between public and private services, or to define whether services are publicly subsidized or not, the extent of public subsidies, nor to assess whether service providers are obliged to comply with standards and regulations set up by public authorities. As an example, both the OECD Family Database and the Multilinks Project clearly set the objective to provide indicators on coverage by public or publicly subsidized formal childcare services. A closer look at the sources used in both databases shows nevertheless that the EU-SILC, which includes places in private facilities and services, is used in the OECD Family Database to define the enrolment rate of children aged 0-2. Data on coverage from the Eurostat 2004 report, also including private arrangements, is also used in both OECD and Multilinks databases.

Table 24.2 provides a non-exhaustive overview of the content of these databases, structured along four dimensions of ECEC services; governance, availability, quality, and. While the significant number of databases included in this table might seem to indicate a fairly high availability of useful indicators, it is important to emphasize that the original sources of many indicators are the same in many of the separate datasets. In particular, most childcare policy databases rely heavily on EU-SILC data. Data provided in the DICE database rely mainly on the Eurydice country reports and are not aggregated in a single database but made accessible in separate files. Similarly, data included in the Eurydice reports $(2014 / 15,2019)$ are not aggregated in a database but available through the publications. 
Table 24.2 Overview of data availability on childcare services

\begin{tabular}{|c|c|c|}
\hline & Content & Databases \\
\hline \multirow[t]{3}{*}{ Governance } & $\begin{array}{l}\text { Organization of ECEC } \\
\text { (split/unitary) }\end{array}$ & $\begin{array}{l}\text { Eurydice (2018/19); OECD } \\
\text { Family database (2017); DICE } \\
(2012 / 13)\end{array}$ \\
\hline & $\begin{array}{l}\text { Authorities responsible for } \\
\text { governing ECEC (split/unitary) }\end{array}$ & Eurydice $(2018 / 19)$ \\
\hline & $\begin{array}{l}\text { Measures to facilitate transition } \\
\text { between different types of } \\
\text { centre-based ECEC settings } \\
\text { around age } 3\end{array}$ & Eurydice $(2018 / 19)$ \\
\hline \multirow[t]{5}{*}{ Availability } & $\begin{array}{l}\text { Legal entitlement to a place in } \\
\text { (public) childcare }\end{array}$ & $\begin{array}{l}\text { DICE (2016); Family Policy } \\
\text { Database (2003); Multilinks } \\
(2004,2009) ; \text { Eurydice } \\
(2018 / 19)\end{array}$ \\
\hline & $\begin{array}{l}\text { Enrolment rates in ECEC, incl. } \\
\text { private settings for children } \\
0-3\end{array}$ & $\begin{array}{l}\text { DICE (2003/5-2012); } \\
\text { TransMONEE (1980-2015); } \\
\text { UNECE (2000-2014); Family } \\
\text { Policy Database (1997, 2003); } \\
\text { Work-family policy indicators } \\
\text { (2000); NOSOSCO } \\
\text { (1990-2017); Multilinks (2004, } \\
\text { 2009); OECD Family Database } \\
\text { (2005-2017); Eurydice } \\
\text { (2018/19); EU-SILC (2005-2018) }\end{array}$ \\
\hline & $\begin{array}{l}\text { Enrolment rates in ECEC, incl. } \\
\text { private settings for children } \\
3-5 \text { or compulsory school age }\end{array}$ & $\begin{array}{l}\text { DICE (2003/5-2012); } \\
\text { TransMONEE (1980-2015); } \\
\text { UNECE (2000-2014); Family } \\
\text { Policy Database (1997, 2003); } \\
\text { Work-family policy indicators } \\
\text { (2000); NOSOSCO } \\
\text { (1990-2017); Multilinks (2004, } \\
\text { 2009); OECD Family Database } \\
\text { (2005-2017); Eurydice } \\
\text { (2018/19); EU-SILC (2005-2018) }\end{array}$ \\
\hline & $\begin{array}{l}\text { Enrolment rates in ECEC, incl. } \\
\text { private settings in } \\
\text { out-of-school care }\end{array}$ & $\begin{array}{l}\text { DICE (2003/5-2012); NOSOSCO } \\
\text { (1990-2017); Multilinks (2004, } \\
\text { 2009); OECD Family Database } \\
\text { (2017); EU-SILC (2005-2018) }\end{array}$ \\
\hline & $\begin{array}{l}\text { Reason for not meeting needs } \\
\text { for formal childcare services }\end{array}$ & EU-SILC (2016) \\
\hline
\end{tabular}


Table 24.2 (continued)

\begin{tabular}{|c|c|c|}
\hline & Content & Databases \\
\hline & $\begin{array}{l}\text { Opening hours/average weekly } \\
\text { hours }\end{array}$ & $\begin{array}{l}\text { Multilinks (2004, 2009); DICE } \\
\text { (2005-2012); OECD Family } \\
\text { Database (2005-2017); Family } \\
\text { Policy Database (2003); } \\
\text { Eurydice (2018/19); EU-SILC } \\
\text { (2005-2018) }\end{array}$ \\
\hline \multirow[t]{8}{*}{ Quality } & Child-to-staff ratios & TransMONEE; DICE (2012/2013) \\
\hline & $\begin{array}{l}\text { in pre-primary education } \\
\text { services }\end{array}$ & $\begin{array}{l}\text { OECD Family database (2016); } \\
\text { Family Policy Database (2003); } \\
\text { DICE (2012/2013); Eurydice } \\
(2018 / 19)\end{array}$ \\
\hline & $\begin{array}{l}\text { In early childhood educational } \\
\text { development services }\end{array}$ & $\begin{array}{l}\text { OECD Family database (2016); } \\
\text { Family Policy Database (2003); } \\
\text { Eurydice }(2018 / 19)\end{array}$ \\
\hline & $\begin{array}{l}\text { Minimum qualifications required } \\
\text { for ECEC staff in the care } \\
\text { sector }\end{array}$ & $\begin{array}{l}\text { OECD Family database (2012); } \\
\text { DICE (2012/2013); Eurydice } \\
(2018 / 19)\end{array}$ \\
\hline & $\begin{array}{l}\text { Minimum qualifications required } \\
\text { for teaching staff in } \\
\text { education-focused ECEC } \\
\text { services }\end{array}$ & $\begin{array}{l}\text { OECD Family database (2012); } \\
\text { DICE (2012/2013); Eurydice } \\
(2018 / 19)\end{array}$ \\
\hline & $\begin{array}{l}\text { Minimum qualifications required } \\
\text { by age }\end{array}$ & $\begin{array}{l}\text { DICE (2012/2013); Eurydice } \\
(2018 / 19)\end{array}$ \\
\hline & ECEC staff compensation & Family policy database (2003) \\
\hline & Educational guidelines & Eurydice $(2018 / 19)$ \\
\hline \multirow[t]{6}{*}{ Affordability } & $\begin{array}{l}\text { Public spending on childcare } \\
\text { and early education }\end{array}$ & $\begin{array}{l}\text { OECD Family database } \\
\text { (1980-2017); Family Policy } \\
\text { Database (2003); DICE (2011) }\end{array}$ \\
\hline & $\begin{array}{l}\text { Expenditure on ECEC as \% of } \\
\text { GDP in public and private } \\
\text { settings }\end{array}$ & $\begin{array}{l}\text { OECD Family database } \\
\text { (1980-2017); Family policy } \\
\text { database (1997) }\end{array}$ \\
\hline & $\begin{array}{l}\text { Childcare costs (couple and } \\
\text { single parent households) }\end{array}$ & $\begin{array}{l}\text { OECD Benefits and Wages } \\
\text { (2015); Multilinks (2004); DICE } \\
\text { (2012); Eurydice (2018/19) }\end{array}$ \\
\hline & $\begin{array}{l}\text { Financial support to parents for } \\
\text { ECEC }\end{array}$ & $\begin{array}{l}\text { Family Policy database (2003); } \\
\text { DICE (2012/13); Eurydice } \\
(2018 / 19)\end{array}$ \\
\hline & $\begin{array}{l}\text { Reason for not meeting needs } \\
\text { for formal childcare services }\end{array}$ & EU-SILC (2016) \\
\hline & $\begin{array}{l}\text { Level of difficulty to afford } \\
\text { formal childcare services }\end{array}$ & EU-SILC (2016) \\
\hline
\end{tabular}

Note Last updated May 2020 
The governance and the organization of childcare services are key instruments to ensure available and accessible services. Fully integrated systems and unitary systems seem to offer greater coherence in the supply of places throughout the age groups and to be associated with improved care quality and more equitable provision of services (European Commission, 2019). Information about governance is only available in Eurydice publications $(2014 / 15,2019)$ and in the OECD Family policy database, although information is less detailed in the latter.

Availability is perhaps the most basic feature of childcare provision, as services need to be available in the first place before other features can become relevant. Although sometimes conceptualized as separate features, issues regarding accessibility and flexibility might also be seen as aspects of availability. Generally, availability is operationalized using enrolment rates, and a quick look at Table 24.1 reveals that most of the data collection efforts have indeed focused on this indicator. This, as argued before, is somewhat unfortunate since the actual use of childcare services is the result of a combination of several factors (Javornik, 2014). As an alternative institutional measure some have instead opted for an indicator of the existence of a legal entitlement to a place in a childcare setting (Saraceno \& Keck, 2008).

Although the entitlement to be granted a place in public childcare is by now fairly well mapped, the data has until recently not allowed grasping crosscountry differences in terms of opening hours and flexibility in this regard, including the availability of services during nonstandard hours. The inclusion of such indicators in the Eurydice key data on Early Childhood Education and Care has however greatly improved the possibility to assess these aspects within a comparative approach (Yerkes \& Javornik, 2018). Less is however known about conditions under which a place in childcare is granted, and how factors related to the family, such as family composition, income, or the parents' employment status, influence the entitlements of children. Being unemployed or on parental leave for instance might affect the number of hours a child is allowed to be in a childcare setting, as well as the associated fee. This aspect is partially tackled in the Eurydice report (2019) but only as regards children living in poverty.

Regarding the affordability of childcare, few databases have given an attempt to calculate the costs of childcare for different family types. The contribution of the OECD (further used by Multilinks and DICE) are particularly valuable in this context. Here, net costs of using childcare services are calculated for six family scenarios involving two types of households (lone parent and couple households with two children) at different earnings 
levels. Based on Eurydice publications, ${ }^{3}$ DICE has moreover collected data on financial support that parents can be granted in order to afford the cost of childcare. Fees are also provided in Eurydice's comparative reports, but these figures might not be fully comparable across countries. Finally, the ad hoc module "Access to services" implemented in EU-SILC in 2016 includes indicators referring to the affordability of childcare services. With available indicators, it might however be difficult to assess how costs vary depending on family income, parental employment, and type of setting. More detailed information about funding schemes and cost regulations is needed in order to assess how affordability varies across groups within countries, and between different types of providers (Yerkes \& Javornik, 2018).

As mentioned earlier, the quality of care matters from the perspective of child development, and is often considered as necessary in order for childcare services to actually promote social integration and equality of opportunity (European Commission, 2013; Van Lancker, 2013). Perceptions of quality may moreover influence parents' attitudes toward the usage of childcare services (Yerkes \& Javornik, 2018). While a common definition of childcare quality is lacking, existing accounts often distinguish between structural and process quality. Structural quality here refers to different aspects relating for instance to the conditions of the staff (educational requirements, salaries), or to the features of the care setting (group sizes, child-to-staff ratios), while process quality is situated at the level of interaction between staff and children and refers to the care-related and pedagogical activities taking place in the childcare setting (OECD, 2018; Penn, 2012; Van Lancker, 2013; Yerkes \& Javornik, 2018).

In practice, process quality figures scarcely in comparative research, much due to the lack of comparable indicators (Yerkes \& Javornik, 2018). Structural quality is most commonly operationalized with reference to child-tostaff ratios and the required educational qualifications for the staff in childcare settings. Moreover, only the OECD Family database and DICE provide updated information about the requirements in terms of education for the staff, as well as regarding the legislation on group size and/or child-to-staff ratios. Again, the role of policy in ensuring a certain quality of the services is not always easy to disentangle, as substantial variation in actual provision between providers might remain despite the norms set by governments. Also, the available data do not allow to distinguish between public and private settings, again potentially obscuring the role of policy in shaping actual provision.

\footnotetext{
${ }^{3}$ Available from 2014.
} 
In addition to direct measures of different features of quality in childcare settings, parents' subjective perception of quality might also relevant for their attitudes toward childcare and sequentially for their inclination to make use of these services. ${ }^{4}$ This is accordingly a highly relevant indicator to understand why families chose different work-family arrangements. However, it can be hard for parents to assess the actual quality of the services on offer (Vandenbroeck \& Lazari, 2014), and there might be multiple factors shaping parents' perceptions of quality. Accordingly, one needs to be cautious when analyzing public policies, structural and process quality, and parent's perceptions thereof.

To summarize, data on childcare services have been made increasingly available, on a growing number of policy dimensions. However, the development has been highly uneven across time and policy fields, resulting in a patchwork of datasets all using different definitions, concepts, and methods, while several databases rely on the same original sources. An important observation is also that data collection has often been initiated from the political sphere, motivated by a need to monitor progress on prioritized issues. In the concluding section, we briefly discuss these observations and call for more academically driven efforts to collect data-based well-defined and theoretically grounded concepts.

\section{Conclusion: A Look Ahead}

This article has been concerned with the availability of conceptually relevant indicators for comparative family policy research. The existing challenges and some potential solutions have been discussed using childcare policy as an example, in order to illustrate the challenges associated with comparative research in this field. Underlying the narrative above is the awareness that analytical research, engaged in explaining important social phenomena, is dependent on reliable empirical indicators, grounded in relevant theory. The consequences of data limitations will accordingly become increasingly evident as the interest of researchers become oriented toward explanation rather than description.

Improved data could, for example, facilitate inquiries about why countries differ substantially with respect to the availability, affordability, and quality of their childcare services, as well as with respect to the timing of its implementation and the mode of governance. As the distributional consequences

\footnotetext{
${ }^{4}$ Eurofound has a question on quality of services in their European Quality of Life surveys (waves in 2003, 2007, 2011, and 2016), which is based on a subjective assessment of respondents.
} 
associated with the reorientation of welfare states according to a social investment logic is being increasingly scrutinized (Bonoli et al., 2017), researchers interested in childcare policy might in addition be in a better position to explain variation in the uptake of childcare services across socioeconomic groups, with reference to variation between national policy frameworks (Korpi et al., 2013). Another question, for which more detailed institutional indicators might be of high relevance relates to how and to what extent the outcomes of childcare policies depend on the interaction between different policy instruments, that is, exploring the role of institutional complementarities. Also, increasing marketization in childcare provision is expected to sharpen inequalities in usage and quality of the services on offer, but to empirically scrutinize such expectation indicators differentiating between public and private provision should be available. Corresponding questions and associated implications with regard to the requirements on available data can be raised in relation to other family policy instruments.

Having access to well-defined institutional indicators not only facilitates studies with explanatory aims. Disentangling institutions from their associated outcomes makes it possible for researchers to redefine the normatively based purposes of specific policies and to analyze policy impacts on outcomes deemed as relevant from a normative viewpoint. Better data can accordingly also contribute to more critical assessments about the ends and goals of contemporary family policies, and how these relate to changing perceptions about families, work, gender, old age, and childhood. Innovative research on childcare policy have in this vein recently come to ask how policy variations influence cross-country differences in parents' agency, in terms of their real opportunities to arrange childcare according to their potentially divergent desires (Yerkes \& Javornik, 2018).

Although an important step forward, developing institutional indicators that reflect national policy frameworks will not be a panacea for all the challenges that comparative family policy analysts currently grapple with. The question of how to deal with variations on subnational levels still remains to be thoroughly discussed and examined, as current practices of using averages or "typical" policies will increasingly be called into question. Also, the issue of implementation and evaluation unescapably comes to the fore. As the focus is shifted toward policy scripts, questions regarding the extent to which policies reflect the actual services delivered by providers, or whether policies are merely a dead letter, will also undoubtedly arise. The need for research that links indicators of policy "supply" with related outcomes will potentially help to critically address this issue. And for some questions, such as the question what actually happens within childcare centers, quantitative approaches 
should be complemented with qualitative approaches as well. Studies of the relationship between structural and process quality are cases in point.

Although this review of the existing literature and databases reveals increasing efforts made over the last decades in the analysis of childcare services, a coherent research infrastructure with institutional childcare indicators, based on theoretically defined concepts, remains elusive. As the above review has indicated, there is a clear need to improve comparability of existing indicators, at the same time as the conceptual framework needs further elaboration in order to improve our understanding of causes and consequences of cross-country differences in childcare policies. We suggest a framework for data collection emphasizing the role of public institutions in structuring availability, affordability, and quality of services. We believe that pursuing the effort to capture cross-country policy variation, is likely to further the research agenda on the role of family policy for social inequality among families with children, between households with and without children, as well as between men and women. Moreover, we think that such an agenda would benefit from a perspective that integrates family policies, including social care services, as essential components of social citizenship.

Acknowledgment The research leading to these results has received funding from the European Union's Horizon 2020 research and innovation program under grant agreement No. 730998, InGRID-2-Integrating Research Infrastructure for European expertise on Inclusive Growth from data to policy.

\section{Databases Included in the Tables}

Boeckmann, I., Budig, M., \& Misra, J. (2012). The work-family policy indicators. Sociology Department, University of Massachusetts-Amherst. https://doi.org/10. 7275/R5WD3XHS.

European Commission. (2019). Key data on early childhood education and care in Europe. 2019 Edition [Eurydice Report]. Luxembourg: Publications Office of the European Union.

Eurostat. (2019). Income and living conditions: Childcare arrangements. Retrieved from https://ec.europa.eu/eurostat/web/income-and-living-conditions/data/dat abase.

Gornick, J., \& Meyers, M. (2003). Family policy database, Version 2. Retrieved from https://www.lisdatacenter.org/resources/other-databases/.

Ifo Institut. (n.d.). Database for Institutional Comparisons of Economies (DICE). Retrieved from https://dice.ifo.de/en. 
Multilinks Database. (2011). Multilinks database on intergenerational policy indicators. Version 2.0. Multilinks Project and Wissenschaftszentrum Berlin für Sozialforschung (WZB). Retrieved from https://multilinks-database.wzb.eu.

NOSOSCO. (2019). Social protection in the Nordic countries. Nordic Social Statistical Committee (NOSOSCO). Retrieved from http://www.nowbase.org/dat abase.

OECD. (2019). OECD family database. OECD: Social Policy Division-Directorate of Employment, Labour and Social Affairs. Retrieved from http://www. oecd.org/els/family/database.htm.

UNICEF. (2019). TransMONEE 2019 database. UNICEF Europe and Central Asia Regional Office: Planning, Monitoring and Evaluation Section. Retrieved from http://transmonee.org/.

UNECE. (2019). UNECE statistical database. United Nations Economic Commission for Europe. Retrieved from https://w3.unece.org/PXWeb2015/pxweb/en/ STAT/STAT_30-GE_98-GE_LifeBalance.

\section{References}

Abendroth, A.-K., \& Den Dulk, L. (2011). Support for the work-life balance in Europe: The impact of state, workplace and family support on work-life balance satisfaction. Work, Employment \& Society, 25(2), 234-256. https://doi.org/10. 1177/0950017011398892.

Adema, W., Huerta, M. C., Panzera, A., Thévenon, O., \& Pearson, M. (2009). The OECD family database: Developing a cross-national tool for assessing family policies and outcomes. Child Indicators Research, 2(4), 437-460. https://doi.org/ 10.1007/s12187-009-9044-8.

Allan, J. P., \& Scruggs, L. (2004). Political partisanship and welfare state reform in advanced industrial societies. American Journal of Political Science, 48(3), 496512. https://doi.org/10.1111/j.0092-5853.2004.00083.x.

Anttonen, A., \& Sipilä, J. (1996). European social care services: Is It possible to identify models? Journal of European Social Policy, 6 (2), 87-100. https://doi.org/ 10.1177/095892879600600201.

Armingeon, K., \& Bonoli, G. (Eds.) (2006). The politics of post-industrial welfare states: Adapting post-war social policies to new social risks. Oxon: Routledge. https:// doi.org/10.4324/9780203099520.

Bäckman, O., \& Ferrarini, T. (2010). Combating child poverty? A multilevel assessment of family policy institutions and child poverty in 21 old and new welfare states. Journal of Social Policy, 39(02), 275-296. https://doi.org/10.1017/S00472 79409990456.

Bettio, F., \& Plantenga, J. (2004). Comparing care regimes in Europe. Feminist Economics, 10(1), 85-113. 
Blum, S., Koslowski, A., Macht, A. \& Moss, P. (2018). International Review of Leave Policies and Research 2018. http://www.leavenetwork.org/lp_and_r_repo rts/.

Bonoli, G., Cantillon, B., \& Van Lancker, W. (2017). Social investment and the Matthew effect: limits to a strategy. In A. Hemerijck (Eds.), The uses of social investment. Oxford: Oxford University Press. https://doi.org/10.1093/oso/978 0198790488.003.0005.

Bonoli, G., \& Reber, F. (2010). The political economy of childcare in OECD countries: Explaining cross-national variation in spending and coverage rates. European Journal of Political Research, 49(1), 97-118. https://doi.org/10.1111/ j.1475-6765.2009.01884.x.

Bradshaw, J., Ditch, J., Holmes, H., \& Whiteford, P. (1993). A comparative study of child support in fifteen countries. Journal of European Social Policy, 3(4), 255271. https://doi.org/10.1177/095892879300300402.

Burger, K. (2013). Early childhood care and education and equality of opportunity: Theoretical and empirical perspectives on social challenges. Springer Science \& Business Media.

Castles, F. G. (2003). The world turned upside down: below replacement fertility, changing preferences and family-friendly public policy in 21 OECD countries. Journal of European Social Policy, 13(3), 209-227. https://doi.org/10.1177/095 89287030133001.

Clasen, J., \& Siegel, N. A. (2007). Investigating welfare state change: The "dependent variable problem" in comparative analysis. Cheltenham: Edward Elgar.

Cohen, B. (1989). Structural funding and childcare: Current funding application and policy implications. Brussels.

Cunha, F., \& Heckman, J. (2007). The technology of skill formation. American Economic Review, 97(2), 31-47.

Daly, M. (2011). What adult worker model? A critical look at recent social policy reform in Europe from a gender and family perspective. Social Politics: International Studies in Gender, State \& Society, 18(1), 1-23. https://doi.org/10.1093/ sp/jxr002.

Daly, M. (2019). Children and their rights and entitlements in EU welfare states. Journal of Social Policy, First View, 1-18. https://doi.org/10.1017/S00472794190 00370.

Department of Education. (2019, January). Education provision: Children under 5 years of age. https://www.gov.uk/government/statistics/education-provision-chi ldren-under-5-years-of-age-january-2019.

Deven, F., S. Inglis, P. Moss \& P. Petrie. (1999). Reconciliation of work and family life for men and women and the quality of care services Report on existing research in the European Union. Luxembourg: Office for Official Publications of the European Communities.

Esping-Andersen, G. (1990). Three worlds of welfare capitalism. Cambridge: Polity Press. 
Esping-Andersen, G. (2015). Welfare regimes and social stratification. Journal of European Social Policy, 25(1), 124-134.

Esping-Andersen, G., Gallie, D., Hemerijck, A., \& Myles, J. (2002). Why we need a new welfare state. Oxford: Oxford University Press.

European Commission. (2013). Barcelona objectives. Luxembourg: Publications Office of the European Union. https://doi.org/10.2838/43161.

European Commission. (2017). Commission recommendation establishing the European Pillar of Social Rights. Brussels. https://ec.europa.eu/commission/publicati ons/commission-recommendation-establishing-european-pillar-social-rights_en.

European Commission. (2019). Key data on early childhood education and care in Europe. 2019 Edition. Luxembourg: Publications Office of the European Union. https://publications.europa.eu/en/publication-detail/-/publication/5816a817b72a-11e9-9d01-01aa75ed71a1/language-en/format-PDF/source-102611557.

Eurostat. (2004). Development of a methodology for the collection of harmonised statistics on childcare. Working papers and studies. Luxembourg: Office for Official Publications of the European Communities.

Eurostat. (2020). EU and national quality reports—Eurostat. https://ec.europa.eu/eur ostat/web/income-and-living-conditions/quality/eu-and-national-quality-reports.

Evertsson, M., England, P., Mooi-Reci, I., Hermsen, J., De Bruijn, J., \& Cotter, D. (2009). Is gender inequality greater at lower or higher educational levels? Common patterns in the Netherlands, Sweden, and the United States. Social Politics: International Studies in Gender, State \& Society, 16(2), 210-241. https:// doi.org/10.1093/sp/jxp008.

Evertsson, M., \& Grunow, D. (2016). Narratives on the transition to parenthood in eight European countries: The importance of gender culture and welfare regime. In M. Evertsson \& D. Grunow (Eds.), Couples' transitions to parenthood: Analysing gender and work in Europe (pp. 269-294). Cheltenham, UK and Northampton, MA, USA: Edward Elgar Publishing.

Ferrarini, T. (2006). Families, states and labour markets: Institutions, causes and consequences of family policy in post-war welfare states. Cheltenham: Edward Elgar Publishing.

Ferrarini, T., Nelson, K., \& Höög, H. (2012). From universalism to selectivity: Old wine in new bottles for child benefits in Europe and other countries. In I. Marx \& K. Nelson (Eds.), Minimum income protection in flux (pp. 137-160). Work and Welfare in Europe. Basingstoke: Palgrave Macmillan. https://doi.org/ 10.1057/9781137291844.0010.

Gambaro, L., Stewart, K., \& Waldfogel, J. (2015). A question of quality: Do children from disadvantaged backgrounds receive lower quality early childhood education and care? British Educational Research Journal, 41(4), 553-574. https:// doi.org/10.1002/berj.3161.

Gauthier, A. H. (1996). The state and the family; a comparative analysis of family policies in industrialized countries. Oxford: Oxford University Press. http://ukcata logue.oup.com/product/9780198294993.do. 
Gauthier, A. H. (2000). Public policies affecting fertility and families in Europe: A survey of the 15 member states. European Observatory on Family Matters, Annual Seminar, Sevilla.

Gornick, J. C., Meyers, M. K., \& Ross, K. E. (1997). Supporting the employment of mothers: Policy variation across fourteen welfare states. Journal of European Social Policy, 7(1), 45-70. https://doi.org/10.1177/095892879700700103.

Grönlund, A., \& Magnusson, C. (2016). Family-friendly policies and women's wages-Is there a trade-off? Skill investments, occupational segregation and the gender pay gap in Germany, Sweden and the UK. European Societies, 18(1), 91-113. https://doi.org/10.1080/14616696.2015.1124904.

Hegewisch, A., \& Gornick, J. C. (2011). The impact of work-family policies on women's employment: A review of research from OECD countries. Community, Work \& Family, 14(2), 119-138.

Hobson, B. (2013). Worklife balance: The agency and capabilities gap. Oxford: OUP.

Huber, E., \& Stephens, J. D. (2000). Partisan governance, women's employment, and the social democratic service state. American Sociological Review, 65(3), 323342.

Javornik, J. (2014). Measuring state de-familialism: Contesting post-socialist exceptionalism. Journal of European Social Policy, 24(3), 240-257. https://doi.org/10. $1177 / 0958928714525815$.

Jensen, C. (2009). Institutions and the politics of childcare services. Journal of European Social Policy, 19(1), 7-18. https://doi.org/10.1177/095892870809 8520 .

Jenson, J. (2009). Lost in translation: The social investment perspective and gender equality. Social Politics: International Studies in Gender, State \& Society, 16(4), 446-483. https://doi.org/10.1093/sp/jxp019.

Kamerman, S. B. (2000). Early childhood education and care: An overview of developments in the OECD countries. International Journal of Educational Research, 33, 7-29.

Kangas, O., \& Palme, J. (2007). Social rights, structural needs and social expenditure: A comparative study of 18 OECD countries 1960-2000. In J. Clasen \& N. A. Siegel (Eds.), Investigating welfare state change: The 'dependent variable problem' in comparative analysis. Cheltenham, UK: Edward Elgar Publishing Inc. https:// doi.org/10.4337/9781847206916.00015.

Keck, W., \& Saraceno, C. (2011). Comparative childcare statistics in Europe: Conceptual and methodological fallacies. Multilinks Insights, no. 1.

Keck, W., \& Saraceno, C. (2013). The impact of different social-policy frameworks on social inequalities among women in the European Union: The labour-market participation of mothers. Social Politics: International Studies in Gender, State \& Society, 20(3), 297-328. https://doi.org/10.1093/sp/jxt005.

Korpi, W. (2000). Faces of inequality: Gender, class, and patterns of inequalities in different types of welfare states. Social Politics: International Studies in Gender, State \& Society, 7(2), 127-191. https://doi.org/10.1093/sp/7.2.127. 
Korpi, W., Ferrarini, T., \& Englund, S. (2013). Women's opportunities under different family policy constellations: Gender, class, and inequality tradeoffs in Western countries re-examined. Social Politics: International Studies in Gender, State \& Society, 20(1), 1-40. https://doi.org/10.1093/sp/jxs028.

Korpi, W., \& Palme, J. (1998). The paradox of redistribution and strategies of equality: Welfare state institutions, inequality, and poverty in the Western countries. American Sociological Review, 63(5), 661-687.

Kröger, T. (2011). Defamilisation, dedomestication and care policy: Comparing childcare service provisions of welfare states. International Journal of Sociology and Social Policy, 31(7/8), 424-440. https://doi.org/10.1108/01443331111149860.

Leitner, S. (2003). Varieties of familialism: The caring function of the family in comparative perspective. European Societies, 5(4), 353-375. https://doi.org/10. 1080/1461669032000127642.

Leitner, S., \& Lessenich, S. (2007). (In) dependence as dependent variable: Conceptualizing and measuring 'de-familization'. In J. Clasenem \& N. A. Siegel (Eds.), Investigating welfare state change: The dependent variable problem in comparative analysis (pp. 244-260). Cheltenham: Edvard Elgar.

Leseman, P. P., \& Slot, P. L. (2014). Breaking the cycle of poverty: Challenges for European early childhood education and care. European Early Childhood Education Research Journal, 22(3), 314-326.

Lewis, J. (2001). The decline of the male breadwinner model: Implications for work and care. Social Politics: International Studies in Gender, State \& Society, 8(2), 152-169. https://doi.org/10.1093/sp/8.2.152.

Lewis, J., \& Giullari, S. (2005). The adult worker model family, gender equality and care: The search for new policy principles and the possibilities and problems of a capabilities approach. Economy and Society, 34(1), 76-104.

Lister, R. (2003). Investing in the citizen-workers of the future: Transformations in citizenship and the state under new labour. Social Policy \& Administration, 37(5), 427-443. https://doi.org/10.1111/1467-9515.00350.

Lohmann, H., \& Zagel, H. (2016). Family policy in comparative perspective: The concepts and measurement of familization and defamilization. Journal of European Social Policy, 26(1), 48-65. https://doi.org/10.1177/095892871562 1712.

Maldonado, L. C., \& Nieuwenhuis, R. (2015). Family policies and single parent poverty in 18 OECD countries, 1978-2008. Community, Work \& Family, 18(4), 395-415. https://doi.org/10.1080/13668803.2015.1080661.

Marchal, S., \& Van Lancker, W. (2019). The measurement of targeting design in complex welfare states: A proposal and empirical applications. Social Indicators Research, 143(2), 693-726. https://doi.org/10.1007/s11205-018-1995-z.

Marshall, T. H. (1950). Citizenship and social class. Cambridge: Cambridge University Press.

Meyers, M. K., \& Gornick, J. C. (2003). Public or private responsibility? Early childhood education and care, inequality, and the welfare state. Journal of Comparative Family Studies, 34(3), 379-411. 
Misra, J., Moller, S., Strader, E., \& Wemlinger, E. (2012). Family policies, employment and poverty among partnered and single mothers. Research in Social Stratification and Mobility, 30 (Inequality across the Globe), 113-128.

Montanari, I. (2000). From family wage to marriage subsidy and child benefits: Controversy and consensus in the development of family support. Journal of European Social Policy, 10, 307-333.

Moss, P. (1990). Childcare in the European communities 1985-1990. Brussels: Commission of the European Communities.

Moss, P. (1996). A review of services for young children in the European Union, 19901995. London.

Nieuwenhuis, R., Need, A., \& Van der Kolk, H. (2019). Family policy as an institutional context of economic inequality. Acta Sociologica, 62(1), 64-80. https:// doi.org/10.1177/0001699318760125.

Nieuwenhuis, R., Need, A., \& Van Der Kolk, H. (2012). Institutional and demographic explanations of women's employment in 18 OECD countries, 1975-1999. Journal of Marriage and Famil, 74(3), 614-630. https://doi.org/10. 1111/j.1741-3737.2012.00965.x.

OECD. (2001). Starting strong: Early childhood education and care. Paris: OECD Publications.

OECD. (2007). Babies and bosses—Reconciling work and family life. Paris: OECD Publishing.

OECD. (2017). Pursuit of gender equality: An uphill battle. Paris: OECD Publishing.

OECD. (2018). Engaging young children: Lessons from research about quality in early childhood education and care. Paris: OECD Publishing.

Olivetti, C., \& Petrongolo, B. (2017). The economic consequences of family policies: Lessons from a century of legislation in high-income countries. Journal of Economic Perspectives, 31(1), 205-230.

Orloff, A. S. (1993). Gender and the social rights of citizenship: The comparative analysis of gender relations and welfare states. American Sociological Review, 58(3), 303-328.

Otto, A. (2018). A benefit recipiency approach to analysing differences and similarities in european welfare provision. Social Indicators Research, $137(2)$, 765-788.

Pavolini, E., \& Van Lancker, W. (2018). The Matthew effect in childcare use: A matter of policies or preferences? Journal of European Public Policy, 25(6), 878893. https://doi.org/10.1080/13501763.2017.1401108.

Penn, H. (2012). Childcare markets: Do they work. In E. Lloyd \& H. Penn (Eds.), Childcare Markets: Can They Deliver an Equitable Service? (pp. 19-42). Bristol: Policy Press.

Pettit, B., \& Hook, J. L. (2005). The structure of women's employment in comparative perspective. Social Forces, 84(2), 779-801. https://doi.org/10.1353/sof.2006. 0029.

Pettit, B., \& Hook, J. L. (2009). Gendered tradeoffs: Family, social policy, and economic inequality in twenty-one countries. New York: Russell Sage Foundation. 
Plantenga, J., \& Remery, C. (2005). Reconciliation of work and private life-A comparative review of thirty European countries. Luxembourg: Office for Official Publications of the European Communities.

Plantenga, J., \& Remery, C. (2009). The provision of childcare services: A comparative review of 30 European countries. Brussels: European Commission.

Randall, V. (2000). Childcare policy in the European states: Limits to convergence. Journal of European Public Policy, 7(3), 37-41.

Rauch, D. (2007). Is there really a Scandinavian social service model? A comparison of childcare and elderlycare in six European countries. Acta Sociologica, 50(3), 249-269. https://doi.org/10.1177/0001699307080931.

Rostgaard, T. (2002). Caring for children and older people in Europe-A comparison of European policies and practice. Policy Studies, 23(1), 51-68. https://doi. org/10.1080/0144287022000000082.

Saraceno, C. (2017). Family relationships and gender equality in the social investment discourse: An overly reductive view? In A. Hemerijck (Eds.), The uses of social investment. Oxford: Oxford University Press. https://doi.org/10.1093/oso/ 9780198790488.003.0004.

Saraceno, C., \& Keck, W. (2008). The institutional framework of inter-generational family obligations in Europe-A conceptual and methodological overview. Berlin.

Saraceno, C., \& Keck, W. (2010). Can we identify intergenerational policy regimes in Europe? European Societies, 12(5), 675-696. https://doi.org/10.1080/146 16696.2010.483006.

Thévenon, O. (2011). Family policies in OECD countries: A comparative analysis. Population and Development Review, 37(1), 57-87. https://doi.org/10.1111/ j.1728-4457.2011.00390.x.

Thévenon, O., \& A. Solaz (2014). Parental leave and labour market outcomes: Lessons from 40 years of policies in OECD countries (Working Papers). Institut National d'Études Démographiques (INED).

Van Lancker, W. (2013). Putting the child-centred investment strategy to the test: Evidence for the EU27. European Journal of Social Security, 15(1), 4-28.

Van Lancker, W., \& Ghysels, J. (2016). Explaining patterns of inequality in childcare service use across 31 developed economies: A welfare state perspective. International Journal of Comparative Sociology, 57(5), 310-337.

Vandenbroeck, M., \& Lazzari, A. (2014). Accessibility of early childhood education and care: A state of affairs. European Early Childhood Education Research Journal, 22(3), 327-335.

Van Lancker, W., \& Van Mechelen, N. (2015). Universalism under siege? Exploring the association between targeting, child benefits and child poverty across 26 countries. Social Science Research, 50(March), 60-75. https://doi.org/10.1016/ j.ssresearch.2014.11.012.

Van Mechelen, N., Marchal, S., Goedemé, T., Marx, I., \& Cantillon, B. (2011). The CSB-Minimum Income Protection Indicators Dataset (CSB-MIPI). 11/05 (CSB Working Papers). Herman Deleeck Centre for Social Policy. 
Yerkes, M., Jana, J., \& Kurowska, A. (2019). Social policy and the capability approach: Concepts, measurements and application. Bristol: Policy Press.

Yerkes, M., \& Javornik, J. (2018, November). Creating capabilities: Childcare policies in comparative perspective. Journal of European Social Policy. https://doi.org/ $10.1177 / 0958928718808421$.

Open Access This chapter is licensed under the terms of the Creative Commons Attribution 4.0 International License (http://creativecommons.org/licenses/by/4.0/), which permits use, sharing, adaptation, distribution and reproduction in any medium or format, as long as you give appropriate credit to the original author(s) and the source, provide a link to the Creative Commons licence and indicate if changes were made.

The images or other third party material in this chapter are included in the chapter's Creative Commons licence, unless indicated otherwise in a credit line to the material. If material is not included in the chapter's Creative Commons licence and your intended use is not permitted by statutory regulation or exceeds the permitted use, you will need to obtain permission directly from the copyright holder.

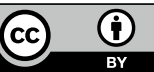

